\title{
ÚJ MODELL IDŐBEN VÁLTOZÓ ERŐFORRÁS-KORLÁTOS ÜTEMEZÉSI FELADATOK MEGOLDÁSÁRA
}

\section{A NEW MODEL FOR SOLVING TIME-VARYING RESOURCE- CONSTRAINED SCHEDULING PROBLEMS}

\author{
Kulcsárné Forrai Mónika ${ }^{1}$, Kulcsár Gyula ${ }^{2}$ \\ ${ }^{I}$ Miskolci Egyetem, Gépészmérnöki és Informatikai Kar, Informatikai Intézet, \\ Alkalmazott Informatikai Intézeti Tanszék, 3515, Magyarország, Miskolc- \\ Egyetemváros; +36-46-565111/19-52,aitkfm@uni-miskolc.hu \\ ${ }^{2}$ Miskolci Egyetem, Gépészmérnöki és Informatikai Kar, Informatikai Intézet, \\ Alkalmazott Informatikai Intézeti Tanszék, 3515, Magyarország, Miskolc- \\ Egyetemváros; +36-46-565111/19-52, iitkgy@uni-miskolc.hu
}

\begin{abstract}
The paper presents a new model for solving time-varying resource-constrained scheduling problems of discrete production processes. The developed model is able to adapt to the requirements of real-life situations by taking into consideration the specific characteristics of modern manufacturing and assembly systems. Our research was focused on scheduling of tool preparation for a complex manufacturing system in automotive industry. The paper describes the most important characteristics of the analysed problem and shows the algorithm of the developed exact solving method.
\end{abstract}

Keywords: production, optimization, scheduling, modelling, algorithm.

\section{Összefoglalás}

A cikk bemutat egy új modellt a diszkrét termelési folyamatok időben változó erőforrás-korlátos ütemezési feladatainak megoldására. A kifejlesztett modell a korszerü gyártó-szerelő rendszerek speciális jellemzőinek figyelembevételével képes valós ipari igények kielégítésére. Kutatómunkánk során egy jármüipari összetett alkatrészgyártó rendszer szerszám-előkészítésének ütemezésére koncentráltunk. A cikk ismerteti a vizsgált feladat legfontosabb jellemzőit és a kifejlesztett egzakt megoldási módszer algoritmusát.

Kulcsszavak: termelés, optimalizálás, ütemezés, modellezés, algoritmus.

\section{Bevezetés}

A termeléstervezés és -ütemezés eredményei általában közvetlenül nem alkalmazhatók a gyártás operatív irányítására, mivel az elkészített tervek összevontan kezelt erőforrásokra alapozott nagyvonalú megoldást alkotnak. A termelésprogramozás (finom vagy részletes ütemezés) feladata az, hogy minden részletre kiterjedő pontos végrehajtási finomprogramot készítsen rövid időhorizontra (pl. heti, napi, müszakonkénti bontásban).

Ahhoz, hogy az elkészített termelési finomprogramok a gyakorlatban megvalósíthatók legyenek, a komplex döntéshozatalnak ki kell terjednie a termelés föfolyamatain túl (gyártás, szerelés) a legfontosabb kapcsolódó mellék 
(pl. logisztikai) és segéd (pl. szerszámellátó) folyamatokra is.

Cikkünkben bemutatunk egy új ütemezési modellt a hozzá tartozó megoldó algoritmussal együtt, amelyek egy konkrét ipari termelésprogramozási feladattípus szerszám-előkészítési részfeladatának megoldását valósítják meg.

\section{A vizsgált ütemezési feladat}

A vizsgált járműipari gyártóműhelyben üléselemeket készítenek különböző márkájú és típusú személyautókhoz. A vevők (jármü-összeszerelő vállalatok) által generált, adott terméktípusra és darabszámra vonatkozó termék-lehívásokat (rendeléseket) szigorúan elöírt szoros határidőre kell teljesíteni.

Az üzem az üléselemek (végtermékek) előállítását körpálya kialakítású gyártórendszerekben valósítja meg. Az üzem gyártórendszerei közösen végzik a rendelések teljesítését. Adott terméktípus általában több pályán is gyártható. Minden egyes pálya adott számú teljes kört (ciklust) tud elvégezni egy müszakban, továbbá adott számú felfüggesztési ponttal (pozícióval) rendelkezik. Adott pálya adott pozíciójához egy adott típusú formahordozó csatlakoztatható, amely kialakítástól függően egy vagy két oldalas lehet. A formahordozó bal és jobb oldalához szerszámok (formák) rögzíthetők a technológia által meghatározott szabályok szerint. Szigorú szabályok írják elő, hogy milyen terméket, melyik pályán, milyen pozícióban, milyen típusú formahordozón, melyik oldalon és milyen más termékkel együtt lehet gyártani.

A pályák önállóan definiált müszakrend szerint müködnek (nyolc órás müszakokat tekintve alapegységnek). Minden egyes müszakban pályánként elöírt darabszámú pozícióban végezhető el csere. Egy csere alapegysége egy formahordozóból és a hozzá kapcsolódó formából (vagy formákból) álló konfiguráció. Adott konfiguráció levétele egy aktív pozícióból és egy elökészített másik konfiguráció felhelyezése ugyanabba a pozícióba jelent egy teljes cserét.

A pályák kialakítása különböző, ezáltal az egy müszakban megtehetö teljes körök száma is eltérő. A termékek gyártásához rendszerint több, eltérő darabszámú forma és formahordozó áll rendelkezésre.

A termeléshez szükséges konfigurációk előkészítését (szét- és összeszerelését) szakképzett dolgozók végzik. Az előkészítési feladat időigényes, így a pályák együtteséből álló üzemben az egy műszakban elvégezhető konfigurációelőkészítések száma szigorú kapacitáskorláttal határolt.

\section{Megoldási koncepció}

A szakirodalomban számos könyv és szakcikk foglalkozik az ütemezési modellekkel és módszerekkel pl. [1], [2], [4], azonban a vizsgált probléma sajátosságaihoz pontosan illeszkedő modellt nem találtunk.

A vázolt korlátozások miatt az üzem terméktípusonkénti termelési intenzitása viszonylag lassan módosítható, így a változatos megrendelések kiszolgálása igen komoly termelésprogramozási feladatot jelent. A szükséges információk rendelkezésre állása alapján a finomprogram jellemzően egy hetes időintervallumra előre készíthető el. A rendszer „lomhasága" miatt szükséges a különböző terméktípusokra egyedileg kalibrált készletszintet fenntartani.

A termelésprogramozási feladat megoldásakor a technológiai és egyéb korlátozások mellett különös figyelmet kell fordítani a konfigurációk előkészítésének korlátaira is.

A vázolt feladat NP-nehéz jellegéből következően a fejlesztés során alapvetően heurisztikus és tudás-intenzív keresési 
technikákra koncentráltunk. Korábban sikeresen alkalmazott modelljeinkből indultunk ki [3].

A feladat döntési változóinak értékét egy többoperátoros és többcélú kereső algoritmus állítja be. A kifejlesztett ütemező szoftver iteratívan módosítja az aktuális ütemtervet, konzisztens változtatásokkal új megoldásokat készít.

A keresési algoritmus egy közbenső lépése által előállított megoldásról meg kell állapítani, hogy az konfiguráció-előkésztés szempontjából megvalósítható-e vagy sem. Ez azt jelenti, hogy az aktuálisan vizsgált termelési programhoz készíteni kell egy megvalósítható konfiguráció-előkészítési ütemtervet, amely a korlátozásoknak megfelel. Ha ez lehetséges, akkor a termelési finomprogram megvalósítható, ellenkező esetben nem.

\section{4. Új ütemezési modell}

A termelésprogramozási (keresési) feladatba beépülő konfiguráció-előkészítési részprobléma önállóan is megfogalmazható ütemezési feladat formájában. A cikk további részében ennek a részproblémának a megoldására térünk ki részletesen.

A konfiguráció-előkészítések (munkák) ütemezési feladata a következőképpen foglalható össze:

- Adott $n$ számú egymástól független $J_{i}$ munka $(i=1,2, \ldots, n)$, önállóan definiált legkorábbi indítási és legkésőbbi befejezési időpontokkal határolva.

- Adott egy erőforrás-rendelkezésre állást definiáló lista, amely átlapolódás nélküli időintervallum-szakaszokból áll, és a kezdési időpontok szerint növekvő sorrendbe rendezett.

- Időintervallumonkénti bontásban rendelkezésünkre áll egy erőforrás halmaz, amely szerelő szakmunkásokból áll, akik az időintervallumokban külön-külön elöírt számú konfiguráció előkészítésére képesek.

- A cél az, hogy készítsünk ütemtervet a korlátozások betartásával úgy, hogy a határidő túllépés maximális értéke a lehetö legkisebb legyen.

$\mathrm{Ez}$ a probléma ebben a formájában nagyon nehezen kezelhetö. Ezért kidolgoztunk egy probléma-transzformációs eljárást, melynek segítségével a problémát átalakítjuk egy továbbfejlesztett párhuzamos gépes ütemezési feladatra, melyben a rendelkezésre álló gépek száma függ az időtől. A transzformáció lényege a következő:

- Az időintervallumokat a mühelyhez rendelt globális rendszerben besorszámozzuk decimális egészekkel. Ezeket a sorszámokat lépéseknek nevezzük $(s)$. A lépések egy összefüggő sorozatot alkotnak, ez helyettesíti az időtengelyt.

- Mivel egy konfiguráció-előkészítés műveleti ideje egy műszak hosszánál nem lehet nagyobb, ezért a müveleti idők rendre egységnyi értéket (lépést) vesznek fel $\left(p_{i}=1\right)$.

- A munkák időadatait rendre átalakítjuk lépésekre: a legkorábbi indítási időpontot a befogadó müszakot követő müszak lépésszámára $\left(r_{i}\right)$, a határidőt a befogadó múszak sorszámára $\left(d_{i}\right)$ váltjuk át, és a teljesítés időpontját a befogadó müszak sorszámával kifejezett alakban keressük $\left(C_{i}\right)$.

- A munka késését szintén egységnyi lépésben mérjük $\left(L_{i}=C_{i}-d_{i}\right)$.

- A szerelő szakmunkások halmazát felcseréljük párhuzamosan működő virtuális gépekre (erőforrásokra), amelyek egyszerre csak egy munkán dolgozhatnak, és minden munkán egyszerre csak egy erőforrás dolgozhat. A virtuális gépek száma lépésenként eltérő lehet, melyet szimbolikusan $P(s)$ jelöléssel fejezünk ki. Az 
időintervallumban elvégezhetö előkészítések számára vonatkozó eredeti korlátozás adja az adott lépésben rendelkezésre álló virtuális gépek számát.

A transzformált feladat megoldására a következő algoritmust dolgoztuk ki:

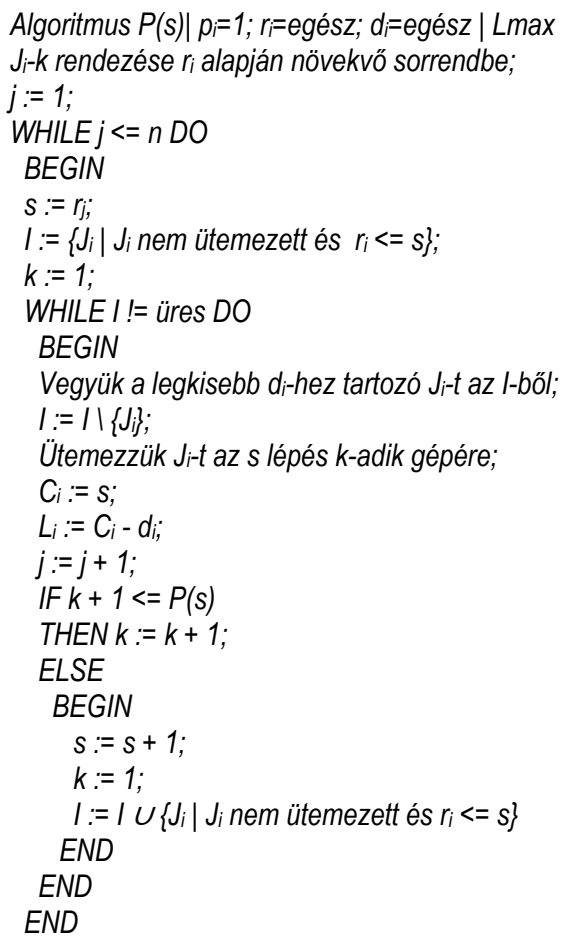

A bemutatott algoritmus minimális késést eredményező megoldást állít elő. Polinomiális futási idő érhető el, ha a munkák indexét az indítási időpontok alapján osztjuk ki. Ha a legnagyobb késés $\left(L_{\max }\right)$ nullánál nem nagyobb, akkor létezik megvalósítható konfiguráció-előkészítési ütemterv a vizsgált termelési programhoz. $\mathrm{Az}$ algoritmus a $C_{i}$ értékek megadásával egyben elő is állítja a keresett megoldást (ütemtervet). A $J_{i}$ munkát (konfigurációelökészítést) a $C_{l}$-edik lépéshez tartozó müszakban kell elvégezni.

\section{Következtetések}

A cikkben ismertettük egy jármüipari összetett termelésprogramozási feladat modellezését és megoldását. A feladat megoldása során a technológiai főfolyamatok mellett különös figyelmet kellett fordítani a szerszám-előkészítési folyamatokra is.

A szerszám-előkészítés ütemezésére egy új modellt dolgoztunk ki, amely időben változó számú párhuzamos gépekből álló erőforrás-környezetet, valamint indítási és befejezési időpontokkal határolt, egységnyi müveleti idejü független munka-halmazt foglal magába. A késések minimalizálására törekedve kidolgoztunk egy feladatspecifikus új megoldó algoritmust, amely polinomiális futási idő alatt optimális megoldás elóállítására képes.

A kidolgozott új ütemezési modell és algoritmus hatékonyan alkalmazható egyrészt összetett termelésprogramozási feladatokban a föfolyamatokhoz kapcsolódó segédfolyamatok időben változó erőforrás-korlátainak figyelembe vételére, másrészt párhuzamosan müködő erőforrások allokálására határidős ütemezési feladatok esetében.

\section{Szakirodalmi hivatkozások}

[1] Allahverdi, A. Ng. C. T., Cheng, T. C. E., Kovalyov M. Y.: A Survey of Scheduling Problems with Setup Times or Costs, European Journal of Operational Research, 187, 2008, 985-1032.

[2] Brucker P.: Scheduling Algorithms, 5th ed, Springer, 2007, 371.

[3] Kulcsár, Gy., Kulcsárné, F. M.: Detailed Production Scheduling Based on MultiObjective Search and Simulation, Production Systems and Information Engineering, Vol. 6, 2013, 41-56.

[4] Pinedo, M. L.: Planning and Scheduling in Manufacturing and Service, 2th ed, Springer, 2009, 537. 